\title{
Exploration of Music Education and Folk Music Cultural Heritage in Colleges and Universities
}

\author{
Jin Pan $^{1, a}$, Dongdong $\mathrm{Xu}^{2}$ \\ ${ }^{1}$ Academy of music, Hankou University, Wuhan 430000, China \\ ${ }^{2}$ Military Physical Education Section of Basic Courses Department, Air Force Early Warning \\ Academy of PLA, Wuhan,Hubei Province,PRC, Wuhan 430019, China
}

a33322659@qq.com

\begin{abstract}
Keywords: Higher Institutions; Music Education;Folk Music Culture;Heritage.
Abstract. Against the backdrop of educational reform, music education becomes more and more important in colleges and universities, by being the important constituent in quality-oriented educational structure in colleges and universities, which can not only cultivate students' music accomplishment, but also push the students' spiritual civilization develop in a healthy way. The traditional Chinese culture is extensive and profound. As an important part, folk music culture fails to actually plays its role in music education in colleges and universities, where the combination of music education and folk music culture is not so tight. In the paper, the author analyzes the heritage of folk music culture in music education.
\end{abstract}

\section{Introduction}

Since the implementation of reform and opening up, as the Chinese culture and western culture integrate with each on a growing basis, the western culture generates profound influence on the ideas and concepts of the students in Chinese colleges and universities. Contrarily, the heritage of folk music culture is neglected in music education in colleges and universities. Pitifully, it even has the inclination to the form of the western culture. As a result, the status of folk music culture is seriously shocked in music education in colleges and universities. The music educators in Chinese colleges and universities shall profoundly realize the importance of folk music culture and be active in integrating folk music culture into music education, which will largely help the students cultivate national and patriotic spirit.

\section{First, Current Development Situation of Music Education in Colleges and Universities}

With the reform and improvement of new curriculum standards, the status of music subject gradually improves in educational structure in colleges and universities. However, from the current development situation of music education in Chinese colleges and universities, China still lags behind the developed countries in terms of the contents, standards and forms of music education, by failing to give full play to the importance of music education in the growth and education of students. In the paper, the author conducts the investigation of music education in the three aspects, i.e., colleges and universities, lecturers and students, to know their opinions about music courses. The specific data are shown in Table One, Table Two and Table Three as follows,

Table One Situation of Music Education Implementation in Colleges and Universities

\begin{tabular}{lll}
\hline Project & Yes & No \\
\hline Percentage & $21 \%$ & $79 \%$ \\
\hline
\end{tabular}

Table Two Attitude of Lecturers towards Music Education

\begin{tabular}{ccccc}
\hline Project & $\begin{array}{c}\text { Very } \\
\text { Important }\end{array}$ & Important & Medium & $\begin{array}{c}\text { Not } \\
\text { Important }\end{array}$ \\
\hline Percentage & $6 \%$ & $14 \%$ & $23 \%$ & $57 \%$ \\
\hline
\end{tabular}


Table Three Students’ Attitude towards Music Course

\begin{tabular}{cccccc}
\hline Project & $\begin{array}{c}\text { Greatly } \\
\text { Interested }\end{array}$ & Interested & $\begin{array}{c}\text { Not } \\
\text { Interested }\end{array}$ & $\begin{array}{c}\text { Having No } \\
\text { Feeling }\end{array}$ \\
\hline Percentage & $61 \%$ & $29 \%$ & $2 \%$ & $8 \%$ \\
\hline
\end{tabular}

Above all, it suggests that many Chinese colleges and universities do not realize the importance of music education; hence, the implementation situation of music education is not so optimistic in colleges and universities. In the perspective of lecturers, 57\% lecturers hold the view that music education is not important. The music courses in general colleges and universities are occupied by other so-called "major" subjects. In the angle of students, most of them are heavily interested in music. Because the combination of music with life and study can help them alleviate the tremendous pressure from study and promote stable development of modern students' physical and mental health[1].

\section{Second, Heritage of Folk Music Culture in Music Education in Colleges and Universities}

Firstly, to highlight the role of folk music culture in music education

While implementing music education in Chinese colleges and universities, it is still restricted by traditional teaching ideas; hence, it is impossible to give play to the importance of folk music culture in music education. Therefore, music teachers in modern times shall establish correct teaching concept and highlight the practical value of folk music culture in music education, thus enabling more students to grasp traditional Chinese culture and promote music education develop in a diversified way. In face of the invasion of western music forms, colleges and universities shall face up to the foreign music culture and do not blindly follow it; instead, they shall learn and draw lessons from foreign music culture with clear mind, to inherit the spirit of Chinese folk music culture and cultivate students' national and patriotic spirit[2].

Secondly, to deepen students' understanding towards folk music culture

Lecturers in colleges and students shall adopt diversified teaching means to deepen students' understanding towards folk music culture and improve students' understanding and appreciative capabilities towards music by appreciating some typical folk music. Besides, the multimedia technology can be applied appropriately to deliver the traditional folk music to the students in a more vivid manner, thus making the students deeply sense the distinctive glamour of folk music culture. In the meanwhile, colleges and universities shall periodically organize the students to collect folk songs in the minority and mountainous areas, which can help students contact the music cultures in different ethnic groups by field investigation; and adhere to the basic principle of "stepping out and drawing in”, to integrate more folk music culture into the music education in colleges and universities[3]. The following Picture One and Picture Two are the performance of folk music cultural artists on stage.

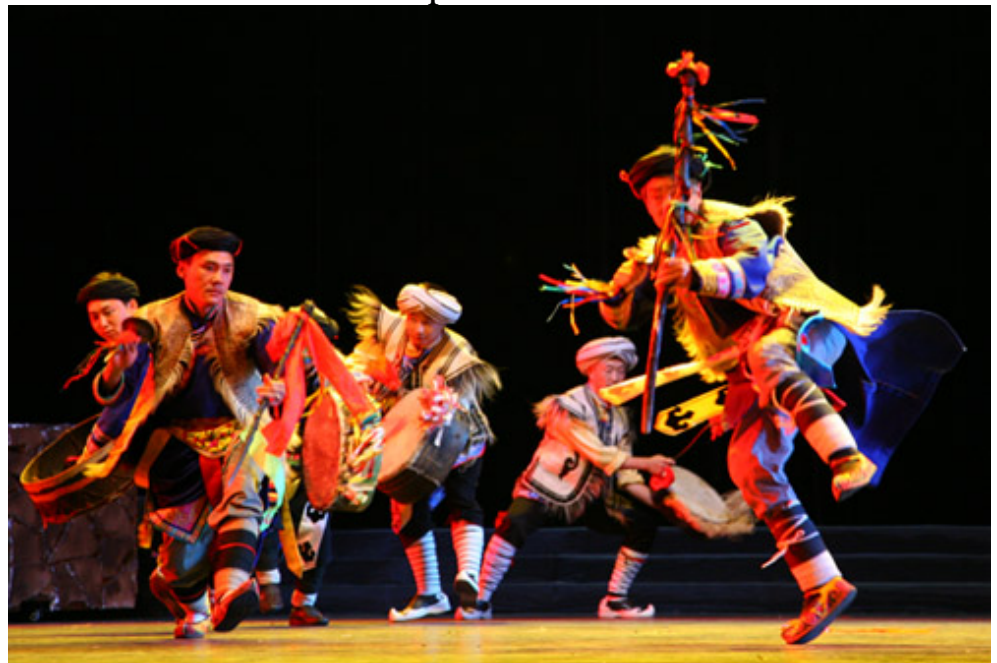

Picture One Performance of Folk Music Cultural Artists on Stage 


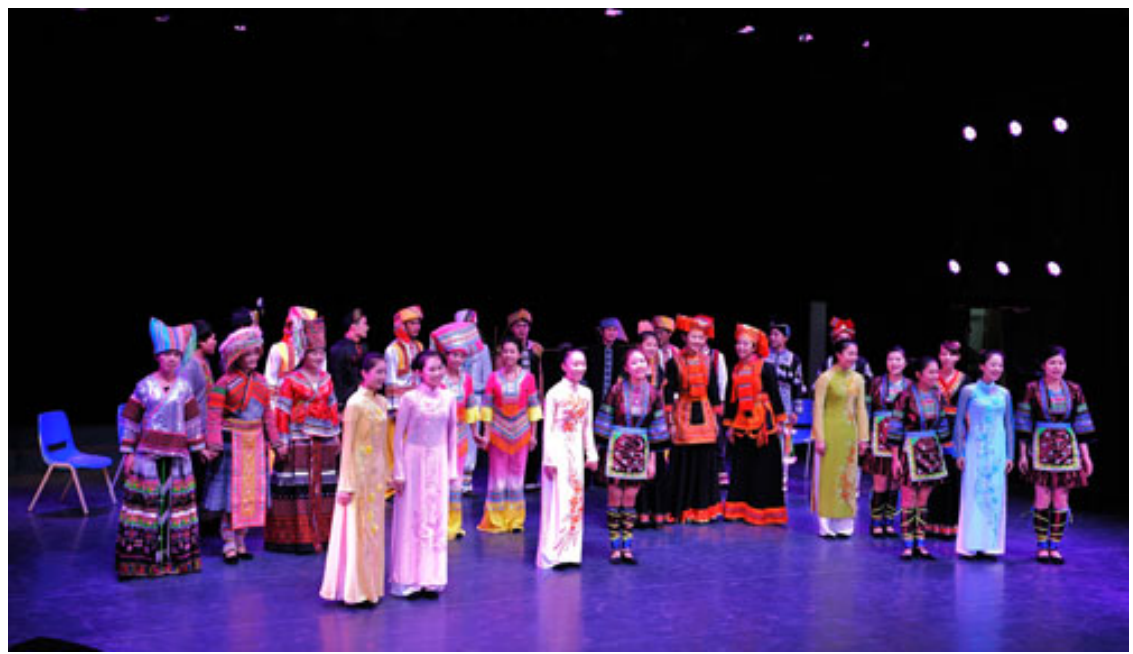

Picture Two Performance of Folk Music Cultural Artists on Stage

Thirdly, to improve the teaching model by combining with folk music culture

In order to better integrate folk music culture with music education, colleges and universities shall improve teaching model on the basis of folk music culture, break traditional music teaching model, progressively get rid of the stale and bring forth the fresh, broadcast some excellent folk music works at class, to enable the students sense the aesthetics of folk music during appreciation. In the meanwhile, lecturers shall make the systematic classification of traditional folk music and help students correctly realize the differences between traditional folk music and modern music, especially grasp the music contents, habits, common points and differences etc. in music among different ethnic groups, to make the students more proficiently grasp folk music culture. In addition, lecturers shall choose some representative folk music to carry out situational teaching, thus making the students integrated into the folk music culture and sense the connotations of folk music culture in person, so as to enhance the quality and efficiency of music teaching in colleges and universities[4].

\section{Conclusion}

All in all, the music education in colleges and universities shall highlight the importance of folk music cultural heritage, actively integrate folk music culture into music education, improve the quality of music education by means of folk music culture, help students establish strong national self-esteem and sense of responsibility, to make the students sense the distinctive glamour of folk music culture in person, and inherit and develop traditional Chinese folk culture by subtle influence, to further strength the students' music accomplishment, which plays a positive role on students' mental health as well as stable ideological and political development.

\section{References}

[1]Liu A H, Ya-Wei A I. Crossing "Forbidden Zone": Practical Exploration and Theoretic Interpretation on the Industrial Management of Folk-Culture[J]. Journal of Shanxi Normal University, 2013, 168(168):210 - 213.

[2]Kang S, Kim K, Ryan C, et al. What Makes People Travel to Cultural Heritage Festival?[J]. International Journal of Tourism Sciences, 2015, 14(3):70-88.

[3]Eric P. Johnson. The use of folk songs in education: Some examples of the use of folk songs in the teaching of history, geography, economics and English literature[J]. Vocational Aspect of Education, 1969, 21(49):89-94.

[4]Lukin S A H. Cultural Reflection and Identity in Bisaya Folkdance[J]. International Journal of the Humanities, 2008(5):155-160. 